\title{
Integrated approach to study river fluxes, water and sediment sources apportionment in sparsely monitored catchment
}

\author{
Sergey Chalov ${ }^{1}$, Pavel Terskii ${ }^{1}$, Thomas Pluntke ${ }^{2}$, Ludmila Efimova ${ }^{1}$, Vasiliy Efimov ${ }^{1}$, \\ Vladimir Belyaev $^{1}$, Anna Terskaia ${ }^{1}$, Michal Habel ${ }^{3}$, Daniel Karthe ${ }^{4}$, and Christian Bernhofer ${ }^{2}$ \\ ${ }^{1}$ Department of Geography, M.V. Lomonosov Moscow State University, Moscow 119991, Russia \\ ${ }^{2}$ Technische Universität Dresden, Chair of Meteorology, Dresden, Germany \\ ${ }^{3}$ Institute of Geography, Kazimierz Wielki University, Bydgoszcz 85-064, Poland \\ ${ }^{4}$ Engineering Faculty, German-Mongolian Institute for Resources and Technology, Nalaikh, Mongolia \\ Correspondence: Sergey Chalov (hydroserg@mail.ru) \\ Published: 1 August 2019
}

\begin{abstract}
The paper presents an integrated approach for the apportionment of water and sediment sources and pathways in ungauged territories. The approach comprises various elements such as a large-scale semidistributed hydrological and erosion model (using the SWAT tool), a statistical assessment of regular discharge data, the discrimination of runoff sources using end-member mixing analysis (EMMA), the apportionment of sediment sources using fingerprinting technique and sediment concentration and water discharge hysteresis rating curves analyses. The approach has been applied to Western Dvina River Basin (WDRB). The results discussed in the paper indicate main features of the water and sediment regime. The components of the presented framework provide a guide for detailed water and sediment studies making it an inexpensive way to develop a roadmap to understand important hydrological processes at a watershed scale.
\end{abstract}

\section{Introduction}

Riverine fluxes, which represent the amount of chemicals transported along the river, are an important subject in rivers studies. Many rivers face problems related to the uneven spatial distribution of monitoring stations. In transboundary rivers, this is mostly due to discrepancies in monitoring programs of the riparian countries. The latter is being the main cause of significant uncertainties (Alexeevskii et al., 2013; Heininen, 2018) and gaps in knowledge on water and sediment quality of Western Dvina River Basin (WDRB), especially its upper part, which is located in Russia. The Western Dvina has its source in the Valdai Hills, Russia, and then flows just above $1000 \mathrm{~km}$ through Russia, Belarus, and Latvia, where it finally drains into the Gulf of Riga of Baltic Sea. Even though the Western Dvina does not flow through either country, parts of Lithuania and Estonia drain into the WDRB. The gauging network is sparse and data has a lot of gaps, especially related to water and sediment qual- ity (Chalov et al., 2017b). It is characterized by six stations representing a drainage area of $17000 \mathrm{~km}^{2}$ with water discharges monitoring and one single sediment monitoring station at the outlet of the catchment. Testing independent approaches becomes an essential part of sediment studies in such kind of areas (e.g. Chalov et al., 2017a). According to WMO (2008), the recommended minimum station density for gauging stations is between 1 station per $1000 \mathrm{~km}^{2}$ in mountaineous subcatchments, 1 station per $1875 \mathrm{~km}^{2}$ in hilly areas and interior plains, and 1 station per $2750 \mathrm{~km}^{2}$ in coastal areas.

\section{Description of integrated approach}

Multidisciplinary ecohydrological approach at Russian part of WDRB has been established to make a first study of water and sediment transport processes within a territory (Table 1). It is based on integrating independent field and numerical tools (modules) to develop a comprehensive conceptual 
Table 1. Integrated approach to study water and sediment transport.

\begin{tabular}{|c|c|c|c|}
\hline \multirow[t]{2}{*}{ Research scope } & \multicolumn{3}{|c|}{ Module } \\
\hline & Type* & Water & Sediments and tracers \\
\hline \multirow[t]{2}{*}{ A. Sources } & I & \multicolumn{2}{|c|}{$\begin{array}{l}\text { 1. Field reconnaissance and land cover classification } \\
\text { 2. Water and sediment sources sampling } \\
\text { 3. Experimental study on stream flow-river bed mass exchange }\end{array}$} \\
\hline & II & $\begin{array}{l}\text { 1. Discriminating runoff sources using } \\
\text { end-member mixing analysis (EMMA) }\end{array}$ & $\begin{array}{l}\text { 2. Discriminating sediment sources using } \\
\text { fingerprinting technique } \\
\text { 3. Sediment concentration - water discharge } \\
\text { hysteresis rating curves analyses }\end{array}$ \\
\hline \multirow[t]{2}{*}{$\begin{array}{l}\text { B. Hydro-logical } \\
\text { pathways }\end{array}$} & I & $\begin{array}{l}\text { 1. Water flux assessment from regular discharge } \\
\text { datasets }\end{array}$ & $\begin{array}{l}\text { 2. Spatio-temporal assessment of water quality } \\
\text { in the WDRB catchment } \\
\text { 3. Sediment and tracers flux analyses from } \\
\text { regular measurements datasets }\end{array}$ \\
\hline & II & $\begin{array}{l}\text { 1. Long term data for flow discharge }(Q) \text { from } \\
\text { available gauges (daily and monthly) } \\
\text { 2. Large scale semi-distributed hydrological } \\
\text { and erosion model (SWAT): } \\
\text { 2a. meteorological ERA-Interim reanalysis } \\
\text { 2b. catchment delineation } \\
\text { 2c. land cover and soil classification } \\
\text { 3. Small scale detailed semi-distributed } \\
\text { hydrological model (SWAT) }\end{array}$ & $\begin{array}{l}\text { 3. Long term data for sediment discharge }(S) \\
\text { from downstream station (Velezh) (event based) } \\
\text { using statistical sediment load model } \\
\text { (LOADEST) } \\
\text { 4. Semi-distributed erosional model using } \\
\text { hydrological SWAT model }\end{array}$ \\
\hline
\end{tabular}

* Field-based (I) or numerical and remote sensing (II) modules.

model of the sources and transport of water, sediment and tracers. Two principal research scales are concerned: sources (A) and hydrological pathways (B) (Table 1). The development of the process-based water, sediment and tracers dynamic integrated approach for pilot study in Western Dvina Basin involved several field-based (I) or numerical and remote sensing (II) modules. The field based studies consisted of field reconnaissance, water and sediment sources sampling, experimental study on stream flow-river bed mass exchange (all related to AI, Table 1) and water flux assessment from regular discharge datasets, spatio-temporal assessment of water quality in the WD catchment, sediment and tracers (total dissolved load) flux assessment from regular discharge datasets obtained (all related to BI, Table 1).

The numerical modules (II) included field-based and remote sensing monitoring program to determine the principal factors of water, sediment and tracers dynamics, application of distributed hydrological model SWAT v.2012 was chosen (Arnold et al., 2012) as a tool to simulate topography, soil and LULC data impact on water balance. The advantages of the SWAT model are the availability of reliable and helpful documentation, absence of limitations on catchment area, compatibility with GIS software (ArcGIS, QGIS, MapWindow), the open-source module of auto calibration SWAT-CUP (Abbaspour et al., 2007). The modeling process of different types of fluxes (water, dissolved and suspended matter) is based on calculations of the river discharge and its parametrization. Based on the catchment inventory, development of soil erosion, sediment transport and deposition modules for channel and hillslope areas separately can be done using statistical model LOAD ESTimator (LOADEST), a FORTRAN program for estimating constituent loads in streams and rivers (Runkel et al., 2004) and integration of these modules with SWAT consistently (1). The models calibration additionally uses results of field-based catchment land cover and soils description and classification. Each of the modules was numbered in 3-digit format (A, B - research scope (sources or pathways); I, II - type (I - field-based; II - numerical and remote sensing); 1, 2, 3, 4, 5- exact tool).

Below we discuss the main results of three modules of the integrated approach - A-II-1, A-II-2 and B-II-2,3. In particular, A-II-1 is aimed to study runoff generation based on hydrochemical assessment of interaction of waters from various water sources of a river in the process of mixing within the river basin based on the samples collected as a part of A-I-2 module (Table 1). A-II-2 module is focused on the identification of the representative sources of sediment and is based on selected tracers (Hooper et al., 1990). B-II-2,3 is based on hydrological model software application of SWAT) (Krengel et al., 2018). Sediment yield in SWAT is estimated with the modified soil loss equation (MUSLE) developed by Williams and Berndt (1972), which is a modification of 


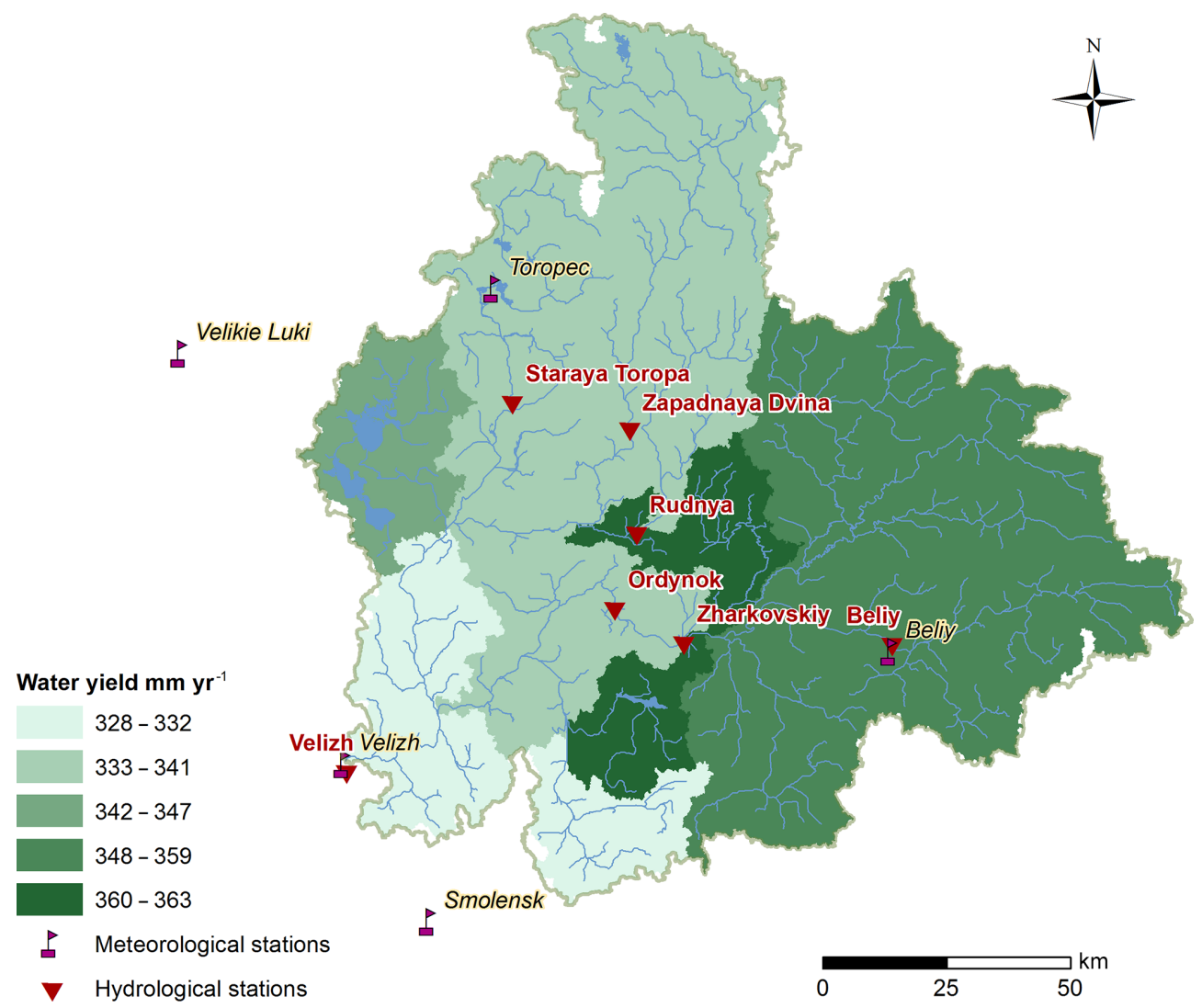

Figure 1. Annual water yield distribution for Russian part of WDRB (SWAT based - mean for 1992-2016).

the standard Universal Soil Loss Equation of Wischmeier and Smith (1960). The results of the field-based catchment land cover and soils description and classification are used for model calibration (modules A-1). Additionally, the land cover classification based on geobotanical descriptions consists of textual vegetation type description. It is used for an automated interpretation of remote sensing images. All images were classified separately using maximum likelihood supervised classification and then merged into mosaic. Initially, 45 classes were produced that were further grouped manually into 12 classes according to NLCD 92 classification (Vogelmann et al., 2001), which can directly be used in SWAT model.

\section{Results and discussion}

The integrated approach (Table 1) was tested as a tool to characterize water and sediment processes within the sparsely monitored WDRB basin. A comparison of meteorological observation data and modelled re-analysis data was undertaken. We recommend to use the interpolated observation data, except the downward solar radiation, because no observations exist. It was investigated, whether a monthly or a daily time step is more appropriate to achieve satisfactory results for the hydrological modelling. Using a detailed dig- ital elevation model DEM (12.5 m) and land use/land cover $(30 \mathrm{~m})$ significantly improve results for a daily time step, but almost does not have any effect for monthly. A sensitivity analysis identified the most important calibration parameters: some "snow" and "groundwater" parameters, and the distributed "rainfall-runoff curve number" parameter. The calibration of "snow" parameters should be done separately, because of the different genesis of snowmelt processes against infiltration and evapotranspiration. Five "snow" parameters were set to naturally adequate ranges for the auto calibration procedure SWAT CUP (Abbaspour et al., 2007). Daily runoff is simulated good (Moriasi et al., 2007) by NashSutcliff efficiency, but annual mean is overestimated (PBIAS reaches $16 \%$ ). Evaporation is simulated well, but snow water equivalent is slightly overestimated (in comparison to observed). We found, that the soil database should be more detailed for daily time step calculations. For the period of model setup 1992-2016, water balance components were calculated: snow melt, actual evapotranspiration, soil water content, percolation, surface runoff, groundwater and lateral flow, total water yield (Fig. 1). Spatial distribution of all simulated water balance components represents the structure of flow generation drivers inside the catchment. It strongly depends on land cover and soil types. The highest evapotranspiration is linked to sub basins with lakes and wetlands 
predomination in the western part of the catchment. Higher snowmelt is linked to higher precipitation in the eastern part. Higher soil water and lower lateral and groundwater flow are linked to gleyic soils and histosols which are dominant under wetlands. The objectives of the EMMA analysis done in the Velesa River basin (module WP A-II-1) were to identify and interpret the potential sources of water in WDRB. The preliminary results indicate a significant variability of underground water sources. The chemical composition of these sources is determined by soil-formation processes and the underlying rocks. The identification and accounting of specific water sources in the EMMA-analysis will make it possible to give an objective assessment of the temporal dynamics in dominant runoff sources and flow paths.

The preliminary results of suspended sediment sources appointment using fingerprinting techniques (working package A II-2) within the Velesa River basin provides valuable information on spatial and temporal variability of the contribution of different sediment sources to the total suspended load. Accordingly, a sediment source fingerprinting technique was used to assess the spatial sources of fine-grained $(<10 \mu \mathrm{m})$ sediments. Total content of selected elements and $137 \mathrm{Cs}$ radioactive isotope was used for discriminating sources to compare it with time-integrated suspended sediment samples (TISSS). The results suggest that the main contributors of fine-grained sediment are the intensively eroded river banks. The results of the sediment source apportionment are in accordance with earlier findings for the rivers of similar size from the forest zone (e.g. Theuring et al., 2013, 2015). According to the obtained results, river bank erosion generates over $70 \%$ of the total fine-grained sediment load. The use of a combination of independent statistical tests helps to take account of potential uncertainties in source estimates, associated with the use of a single composite signature. We found that the application of mobile forms of elements for fingerprinting purposes is questionable, because these may not meet the criteria of conservativeness. Active gullies and river channel erosion sections like undercut banks should be determined in detail based on topographic maps and remote sensing data, which are validated with field data.

This study examines the development of a conceptual framework of water and sediment processes in the catchment scale. Spatially distributing the components of a approach provides a guide for developing more detailed water and sediment budgets. It is inexpensive way to develop a roadmap for understanding the linkages among the various transport processes at a watershed scale. The approach is particularly aimed to provide a full quantitative description of river fluxes and sediment and water quality in poorly gauged catchments. This is very important in areas, where no or only limited sediment-related studies have been done in the past. We found that almost no studies have been devoted to ecohydrology, hydromorphology and sediment transport in transboundary catchments of Eastern Europe (Chalov et al., 2017b; Krengel et al., 2018). The proposed approach might be a useful tool to fill these knowledge gaps.

Data availability. Hydrological data from Russian State Hydrometeorological Agency was used in the study which is the property of this organization. Additionally, future publications of the authors are intended to publish field datasets mentioned in this paper.

Author contributions. SC designed a study concept, CB is the project leader and help to develop the concept of the approach. PT and AT are responsible for SWAt model and satellite data procesing, TP was part of the SWAT modelling group and prepared the climate data. DK made a general text writing and editing, LE and VE have done the water quality study, VB run the fingerprinting model, $\mathrm{MH}$ provided assistance for data analyses.

Competing interests. The authors declare that they have no conflict of interest.

Special issue statement. This article is part of the special issue "Land use and climate change impacts on erosion and sediment transport". It is a result of the ICCE Symposium 2018 - Climate Change Impacts on Sediment Dynamics: Measurement, Modelling and Management, Moscow, Russia, 27-31 August 2018.

Acknowledgements. The authors thank the Volkswagen Foundation for the funding of the project "Management of Transboundary Rivers between Ukraine, Russia and the EU - Identification of Science-Based Goals and Fostering Trilateral Dialogue and Cooperation (ManTra-Rivers)".

Financial support. This research has been supported by the Volkswagen Foundation (grant no. 90 426). Apportionment methodology is developed as a part of Russian Science Foundation project no. 19-77-30004.

\section{References}

Abbaspour, K. C., Vejdani, M., and Haghighat, S.: SWAT-CUP calibration and uncertainty programs for SWAT, Proc. Intl. Congress on Modelling and Simulation (MODSIM'07), 73, 1603-1609, 2007.

Alekseevskii, N., Zavadskii, A., Krivushin, M., and Chalov, S.: Hydrological Monitoring at International Rivers and Basins, Water Resour., 42, 747-757, 2015

Arnold, J. G., Moriasi, D. N., Gassman, P. W., Abbaspour, K. C., White, M. J., Srinivasan, C., Santhi, R., Harmel, D., Van Griensven, A., Van Liew, M. W., Kannan, N., and Jha, M. K.: SWAT: Model use, calibration, and validation, T. ASABE, 55, 1491-1508, https://doi.org/10.13031/2013.42256, 2012. 
Chalov, S., Golosov, V., Tsyplenkov, A., Theuring, P., Zakerinejad, R., Märker, M., and Samokhin, M. A.: toolbox for sediment budget research in small catchments, Geogr. Environ. Sustain., 10, 43-68, https://doi.org/10.24057/2071-9388-2017-10-443-68, 2017a.

Chalov, S., Pluntke, T., Nabyvanets, Y., Kruhlov, I., Helm, B., Terskii, P., Krengel, F., Osadcha, N., Habel, M., Osadchyi, V., Reeh, T., Karthe, D., and Bernhofer, C.: Report on WP A - Assessment of the status quo in the three investigated basins, Interim Report of the Volkswagenstiftung project "Management of Transboundary Rivers between Ukraine, Russia and the EU ...", 10 pp., $2017 b$.

Heininen, L.: Arctic geopolitics from classical to critical approach - importance of immaterial factors, Geogr. Environ. Sustain., 11, 171-186, 2018.

Hooper, R. P., Christophersen, N., and Peters, N. E.: Modelling streamwater chemistry as a mixture of soilwater end-members - an application to the Panola Mountain catchment, Georgia, USA J. Hydrol., 116, 321-343 https://doi.org/10.1016/00221694(90)90131-G, 1990.

Krengel, F., Bernhofer, C., Chalov, S., Efimov, V., Efimova, L., Gorbachova, L, Habel, M., Helm, H., Kruhlov, I., Nabyvanets, Y., Osadcha, N., Osadchyi, V., Pluntke, T., Reeh, T., Terskii, P., and Karthe, D.: Challenges for transboundary river management in Eastern Europe-Three case studies, Die Erde, 149, 157-172 https://doi.org/10.12854/erde-2018-389, 2018.

Moriasi, D. N., Arnold, J. G., Van Liew, M. W., Bingner, R. L., Harmel, R. D., and Veith, T. L.: Model evaluation guidelines for systematic quantification of accuracy in watershed simulations, Am. Soc. Agr. Biol. Eng., 50, 885-900, 2007.
Runkel, R. L., Crawford, C. G., and Cohn, T. A.: Load Estimator (LOADEST): A FORTRAN Program for Estimating Constituent Loads in Streams and Rivers: US Geological Survey Techniques and Methods Book 4, chap. A5, 69 pp., 2004.

Theuring, P., Rode, M., Behrens, S., Kirchner, G., and Jha, A.: Identification of fluvial sediment sources in the Kharaa River catchment, Northern Mongolia, Hydrol. Process., 27, 845-856, https://doi.org/10.1002/hyp.9684, 2013.

Theuring, P., Collins, A. L., and Rode, M.: Source identification of fine-grained suspended sediment in the Kharaa River basin, northern Mongolia, Sci. Total Environ., 526, 77-87, https://doi.org/10.1016/j.scitotenv.2015.03.134, 2015.

Vogelmann, J. E., Howard, S. M., Yang, L., Larson, C. R., Wylie, B. K., and Van Driel, N.: Completion of the 1990s National Land Cover Data Set for the conterminous United States from Landsat Thematic Mapper data and ancillary data sources, Photogramm. Eng. Rem. S., 67, 650-662, 2001.

Williams, J. R. and Berndt, H. D.: Sediment yield computed with universal equation, J. Hydraul. Div., 98, 2087-2098, 1972.

Wischmeier, W. H. and Smith, D. D.: A universal soil-loss equation to guide conservation farm planning, Trans 7 th int Congr. Soil Sci., 1, 418-425, 1960.

WMO: World Meteorological Organization Guide to Hydrological Practices: Volume I Hydrology - From Measurement to Hydrological Information, 6th Edn., Geneva, Switzerland, World Meteorological Organization Publication No. 168, 296 pp., 2008. 